\title{
TYING ARRANGEMENTS AND RECIPROCITY: A LAWYER'S COMMENT ON PROFESSOR FERGUSON'S ANALYSIS
}

\author{
Bernie R. Burrus*
}

Perhaps in no area save the arena of mental responsibility in the criminal law does the average attorney find himself confronted with the rigors of such an explosive and often self-contradictory discipline as in the field of antitrust law. Recent litigation in the federal courts and before the Federal Trade Commission signals the opening of a fresh assault on the business community by a concerned government and public. Having survived the enthusiasm of such "trustbusters" as Teddy Roosevelt and Thurman Arnold, our business giants have been forced to seek more acceptable means of exerting their market power so as to maximize profits within the framework of the existing antitrust laws. If tying provisions written into sales contracts by firms with weighty horizontal market power provide an example of the more sophisticated approach adopted by the business world, the reaction of the modern "trustbusters" and ultimately of the Supreme Court demonstrates an equally ingenious application of antitrust doctrine.

Professor Ferguson has suggested that the antitrust decisions of the courts reflect social policy weighed in equal measure with economic factors in arriving at a particular determination. It is the purpose of this comment to suggest that such a phenomenon is not new and indeed that such a result is the natural and unavoidable consequence of our system, which forces upon bench and bar the adversary roles in all fields of socio-economic decision. The Ferguson article propounds an economic analysis of two of the more modern business practices that have come under attack by the Government, the so-called "tying contract" and the practice of "reciprocity" in buying and selling.

\section{Tying Arrangements}

Professor Ferguson's analysis of tying provisions suggests that the conclusion of the courts that such tie-in contracts are illegal per se is sound in light of the economic factors that must be weighed in dealing with a monopolistic or near-monopolistic market situation. The market conditions under which tying contracts are likely

- B.S. 1955, University of Houston; M.P.A. 1957, Princeton University; LL.B. 1960, New York University; S.J.D. I963, University of Michigan. Professor of Law, Georgetown University Law Center. The author expresses his appreciation to Daniel W. Fessler, Class of 1966, Georgetown University Law Center, for his assistance in the preparation of this paper.

${ }^{1}$ See International Business Machs. Corp. v. United States, 298 U.S. I31 (1936); International Salt Co. v. United States, 332 U.S. 392 (1947); and Northern Pac. Ry. v. United States, 356 U.S. I (1958). 
to arise are exposed with a precision that should lend guidance to government officials and to the courts in future questions surrounding the social utility of this practice. The term "future questions" is used deliberately to allow for legal distinctions that seem to be maturing in at least two decisions of lower federal courts. ${ }^{2}$ Suffice it to indicate that the market advantages articulated by Professor Ferguson have been presented to the district courts with the resulting recognition that tie-in agreements may be justified within the context of the facts presented. ${ }^{3}$

Before leaving this area, it should be noted that tying devices may be attacked under a variety of antitrust laws. Sections $I$ and 2 of the Sherman $\operatorname{Act}^{4}$ have been successfully utilized by the Government in such recent cases as Northern Pac. Ry. $v$. United States, and United States v. Loew's, Inc. ${ }^{6}$ Section 3 of the Clayton Act ${ }^{7}$ may be utilized to enforce a prohibition against tying agreements in the market for goods, and was successfully employed in Signode Steel Strapping Co. v. FTC. ${ }^{8}$ Finally, the Government may resort to section 5 of the Federal Trade Commission $\mathrm{Act}^{9}$ for the most general language under which an enforcement offensive can be mounted.

Despite the developments in Jerrold and Dehydrating Process, ${ }^{10}$ the notion that tying provisions are illegal per se seems to be firmly implanted in the mind of the Supreme Court. Once before the Court seemed to be tending away from the per se doctrine enunciated in International Salt Co. v. United States. ${ }^{11}$ That was in the celebrated Times-Picayune Publishing Co. v. United States, ${ }^{12}$ a 5-4 decision of the Court reversing a district court's application of sections $I$ and 2 of the Sherman Act. Any uncertainty created by that decision was dispelled, however, by the opinion of the majority in Northern Pacific, which took great pains to re-establish the viability of the per se prohibition doctrine.

\section{II}

\section{RECIPROCITY}

If the Ferguson article concludes on an harmonious note with reference to tying provisions, his determination that reciprocity is "not a phenomenon that depends

\footnotetext{
${ }^{2}$ United States v. Jerrold Electronics Corp., 187 F. Supp. 545 (E.D. Pa. 1960), aff'd per curiam, on other grounds, 365 U.S. 567 (1961); Dehydrating Process Co. v. A. O. Smith Corp., 292 F.2d 653 (Ist Cir.), cert. denied, 368 U.S. 931 (1961).

${ }^{3}$ For balanced discussions of the current state of the law with regard to tie-ins, sce Turner, Validity of Tying Arrangements Under the Antitrust Laws, 72 Harv. L. REv. 50 (1958); Paley, Antitrust Pitfalls in Exclusive Dealing: Recent Developments Under the Sherman, Clayton and FTC Acts, 37 NornE Dame Law. 499 (1962); Comment, Use of Tie-Ins in New Industries, 70 Yale L.J. 804 (196r).

26 Stat. 209 (I890), as amended, 15 U.S.C. $\$ 5$ I, 2 (1964).

356 U.S. I (1958).

37 I U.S. 38 (1962).

${ }^{7} 38$ Stat. 731 (1914), 15 U.S.C. \$14 (1964).

8 I32 F.2d 48 (4th Cir. 1942).

${ }^{\circ} 8$ Stat. 719 (I914), as amended, I5 U.S.C. $\$ 45$ (1964).

${ }^{10}$ See note 2 supra and accompanying text.

${ }^{11} 332$ U.S. 392 (1947).

${ }^{12} 345$ U.S. 773 (1953).
} 
on market power" and that "these agreements will not lessen competition and, therefore, are not a proper concern of antitrust," could not be more at variance with the most recent pronouncement of the Supreme Court on the subject. The balance of this comment will concern itself with drawing a contrast between the arguments advanced by Professor Ferguson and the socio-economic convictions of the Federal Trade Commission and, now, the Supreme Court.

These remarks should be prefaced with an observation concerning the major -and often unstated-premise from which the Supreme Court proceeded in the Consolidated Foods case. ${ }^{13}$ The Court is convinced that competition in free markets is the ultimate logic of our private enterprise system and that it must be protected. ${ }^{14}$ It will readily be perceived that in stating this premise the Court has embraced an economic theory and made a social value judgment. Having assumed this posture, the Court has demonstrated a willingness to apply a "rule of reason" in weighing the social advantages of any challenged business practice against its desire to preserve freely competitive markets. The role of this "rule of reason" cannot be over-stressed, for its neglect is to misinterpret what has gone in the past and to invite disaster in the future.

Professor Ferguson demonstrates through a set of hypothetical market-conditions that reciprocity does not depend upon horizontal market power, and from this fact he concludes that no threat to our competitive economic picture is presented that should warrant antitrust prosecution. It is interesting to note that the brief for the FTC in the Consolidated Foods case in the Supreme Court proceeded on a wholly different premise and reached a diametrically opposite conclusion. In essence, the Commission contended-and the Court, speaking through Mr. Justice Douglas, agreed-that it was conglomerate market power that provided the respondent with a market bludgeon that was basically incompatible with a free market.

The Court was faced with a market pattern that cannot be directly equated with any of the three fact settings hypothesized by Professor Ferguson. Consolidated, through its merger with Gentry, had obtained a direct stake in what was already an oligopolistic market for dehydrated onion and garlic. Gentry's products were used by many firms whose finished foods were then purchased and distributed by Consolidated. The merger between Consolidated and Gentry was of the conglomerate variety, in that Consolidated expanded its sphere of market activity into an area previously not encompassed by its marketing operations.

\footnotetext{
${ }^{10}$ FTC v. Consolidated Foods Corp., 380 U.S. 592 (1965), reversing 329 F.2d 623 (7th Cir. 1964).

16 This premise is not always left unstated by the Court. The opinion of Mr. Justice Black in Northern Pac. Ry. v. United States, 356 U.S. I, 4 (I958), contains the following declaration:

"The Sherman Act was designed to be a comprehensive charter of economic liberty aimed at preserving free and unfettered competition as the rule of trade. It rests on the premise that the unrestrained interaction of competitive forces will yield the best allocation of our economic resources, the lowest prices, the highest quality and the greatest material progress, while at the same time providing an environment conducive to the preservation of our democratic political and social institutions."
} 
The FTC took the position that because of this merger, Consolidated was now in a position to transform "purchasing power" in the finished foods market into leverage whereby it could exert pressure upon its sellers to utilize Gentry's ingredient products. In other words, the "purchase credits" would be accumulated by Consolidated and redeemed in the form of orders being placed by these same suppliers with Gentry. It will be observed that before the $195^{\mathrm{I}}$ merger, none of the three suppliers of these dehydrated vegetable products had any such market power. Some ten years following the merger, Gentry's only major competitor, Basic Vegetable Products, Inc., and a minor entrant in the market, Puccinelli Packing Co., were still independent of any similar arrangements, and thus had to fight for their share of the market without the benefit of such an altered market structure. In light of this development, Professor Ferguson's conclusion that such arrangements are not destructive of free competition because, while "competitors are foreclosed from sales at equal prices, ... all firms can practice reciprocity," has not been borne out by the post-acquisition history. Apparently, at least in this market, Basic and Puccinelli have not found it possible to duplicate such a favorable market structure.

The Ferguson article leaves the reader convinced that the author is undisturbed by a market situation in which competitors are foreclosed from sales at "equal prices." The position of the Federal Trade Commission could not be more to the contrary and demonstrates the stark contrast between the approaches of the two arguments. In its brief, the Commission answers this contention by declaring,

It is no answer to assert that the testimony and other evidence merely showed that Gentry would be given preference if all other factors (i.e., price and quality) were equal. To be sure, price and quality standards are significant in the food industry, but this record demonstrates clearly that reciprocity tips the scale if price and quality are evenly balanced. This pinpoints the competitive disadvantage under which Gentry's competitors are forced to labor because of the merger. In order to have an equal opportunity to make sales they must cut their prices, reducing their profit margins, or raise their quality with no price recognition for their superior product. If Gentry can equal their price or match their quality, they will be foreclosed. This is precisely the vice of reciprocity. ${ }^{16}$

The Supreme Court adopted an identical position declaring that "the practice results in 'an irrelevant and alien factor' ... intruding into the choice among competing products, creating at the least 'a priority on the business at equal prices.' "16

Recent litigation before the District Court for the Western District of Pennsylvania presented a similar issue. The court analyzed the net market effect of reciprocal dealing in the following terms:

What may here be involved is the trade practice known as "Reciprocity." This is particularly destructive of competition because it transforms substantial buying power into a weapon for "denying competitors less favorably situated access to the

16 Brief for Petitioner, pp. 38-39.

${ }^{10} 380$ U.S. at 594 . 
market." . . . It distorts the focus of the purchaser by interposing between him and the traditional standards of price, quality and service, an irrelevant and alien factor which is destructive of fair and free competition on the basis of merit. The competitor may thereby suffer loss because of a circumstance not bearing directly on the worth of his product. In this situation, it is the relative size and conglomeration of business rivals, rather than their competitive ability, that may determine success. Obviously, this practice strikes at one of the basic premises of a free enterprise economy. ${ }^{17}$

The language of the two courts is remarkably similar, reflecting, no doubt, the terminology coined by the FTC. And yet, if the words be identical, the underlying suppositions are no less uniform.

In essence; the courts answer the arguments of Professor Ferguson by declaring that their concern must be with the over-all market structure. Thus, even though a merger such as the one in Consolidated Foods can be represented as having had a healthy effect in so far as the business fortunes of the immediate parties were concerned, if the courts are convinced that the long-range effect of such a practice is the "probability that competition in the affected market would be substantially lessened," section 7 of the Clayton Act is approved as a proper remedy. In other words, the Supreme Court has adopted a policy under which it will examine these merger cases via an inquiry that does not focus on overt anticompetitive trade practices as such but rather on changes in the market or industry structure that are effected by the challenged arrangement.

Viewed in this light, the rationale for seeking a divestiture order under section 7 of the Clayton Act becomes evident. Unlike the openly coercive reciprocity tactics attacked in the three Federal Trade Commission cases during the r 930 os, ${ }^{18}$ the Court in Consolidated faced a far more subtle business art. This refinement was recognized by the Supreme Court:

Reciprocal trading may ensue not from bludgeoning or coercion but from more subtle arrangements. A threatened withdrawal of orders if products of an affiliate cease being bought, as well as a conditioning of future purchases on the receipt of orders for products of that affliate, is an anticompetitive practice. Section 7 of the Clayton Act is concerned with "probabilities, not certainties." . . . Reciprocity in trading as a result of an acquisition violates $\$ 7$, if the probability of a lessening of competition is shown. ${ }^{19}$

In the earlier FTC cases, the practices complained of were such blatant violations of the antitrust laws that a simple cease and desist order issued under section 5 of the Federal Trade Commission Act was deemed sufficient. In the instances of the more ingenious and concealed forms of anticompetitive practices, the courts cannot be

\footnotetext{
${ }^{27}$ United States v. Ingersoll-Rand Co., 218 F. Supp. 530, 552 (W.D. Pa.), affd, 320 F.2d 509 (3rd Cir. $I 963$ ).

${ }^{18}$ California Packing Corp., 25 F.T.C. 379 (1937); Mechanical Mfg. Co., 16 F.T.C. 67 (I932); Waugh Equip. Co., 15 F.T.C. 232 (I93I).

${ }^{10}{ }_{380}$ U.S. at $594-95$.
} 
blamed for piercing the smoke screen and rooting out the long-term cause of the market conditions that are giving rise to the offense.

The conglomerate merger is readily identifiable as the villain in many of the reciprocity cases litigated under section 7. As early as 1955 , one commentator was recorded as having noted the market effects of reciprocal dealings between "large and powerful concerns." ${ }^{20}$ Professor Ferguson himself adds strength to this argument when he lists the advantages that a firm can obtain by securing a dependable trading partner. The economies that can be maximized when one's planners can count on a certain minimum volume of sales, the savings encountered in the field of advertising, and finally the long-range strength that a healthy market for one's products is likely to engender make "reciprocal dealings" very attractive to the immediate parties.

Again, in the field of price competition in an already oligopolistic market, the reader need look no further than the analysis supplied by Professor Ferguson to discern the advantages of reciprocal buying favors as a means of giving a price rebate that competitors will find difficult to detect. ${ }^{21}$ If competitors in an oligopolistic market would thus be placed at a trading disadvantage, one need not dwell on the plight of the new entrant into that particular market! To the extent that new entries are thereby discouraged or bankrupted while stumbling about in the darkened "tunnel of reciprocal love," a conglomerate merger that leads to reciprocity is doubly destructive of a free market. Finally, to the extent that they are able to preserve their status as exclusive factors in a particular market, the oligopolists both singly and collectively find it possible to keep prices firm and supply controlled to the end that they are able to equate their marginal revenue and costs at a level high above society's true marginal cost.

It must be conceded that the long-term effect prognosticated in the preceding paragraph involves a rather extended economic reasoning process; however, such an experience with imperfect competition is hardly unknown. ${ }^{22}$ It is at this critical point that one is able to distinguish the final flaw in Professor Ferguson's conclusion and, incidentally, to understand why it is that none of the three models he sets forth adequately meet the conditions facing the courts in recent litigation. Pro-

\footnotetext{
${ }^{20}$ Edwards, Conglomerate Bigness as a Source of Power, in National Bureau of Economio Research, Business Concentration and Price Policy 33r, 342 (1955).

${ }^{21}$ For an excellent analysis of these marketing effects, see Hausman, Reciprocal Dealing and the Antitrust Laws, 77 Harv. L. Rev. 873 (1963). Hausman traces the impact of the conglomerate merger on reciprocity and makes a convincing argument that the two are naturally complementary, having a tendency to be mutually generative.

${ }^{22}$ The following language of Mr. Justice Jackson in International Salt Co. v. United States, 332 U.S. 392, 396 (1947), is discussing tying provisions but serves to demonstrate the Court's careful analysis of long-range market effects:

"The volume of business affected by these contracts cannot be said to be insignificant or insubstantial and the tendency of the arrangement to accomplishment of monopoly seems obvious. Under the law, agreements are forbidden which 'tend to create a monopoly' and it is immaterial that the tendency is a creeping one rather than one that proceeds at full gallop; nor docs the law await arrival at the goal before condemning the direction of the movement."
} 
fessor Ferguson is concerned with the concept of horizontal market power as being utilized to gain advantage within the ambit of that particular market. The Consolidated Foods case, on the other hand, is concerned with the problem of a conglomerate merger whereby the dominant factor reaches into an area of economic activity in which it had previously had but a tangential interest. Thus it seeks to exert its "market leverage" in a virgin sector of the over-all market. It is at this juncture that the competitors in the affected market become the victims of the practice in the manner described by the Federal Trade Commission and the Supreme Court. ${ }^{23}$

Having concluded a discussion of the Court's rationale, it is important to note what the Consolidated Foods decision does not stand for. At no point in the opinion, is there language that would support the conclusion that reciprocity, standing alone, is per se illegal. ${ }^{24}$ Indeed, the presence of the merger issue as the dominant factor in the litigation renders much of the Court's decision subject to further elucidation. Reciprocity was but a tool employed by the respondent in a market setting that made its utilization an unfair trade practice. Because the litigation was conducted under section 7 of the Clayton Act, we are left in doubt as to which of the other provisions of the antitrust laws would be used by the Government if, and when, it chooses to prosecute a "pure reciprocity case."

In this connection, mention should be made of the recent memorandum opinion of Judge Cannella in United States v. General Dynamics Corp. ${ }^{25}$ In denying defendant's motion, at the close of the Government's case, to dismiss "on the ground that upon the facts and the law the plaintiff has shown no right to relief," the court stated that the Government had made out a cause of action under both section 7 of the Clayton Act and section I of Sherman. Involved was a conglomerate merger and a special sales program, both with alleged reciprocal aspects. Defendant's claim that reciprocal dealing arrangements are not violative of section 7 was, as might be expected, disposed of by the court on authority of Consolidated Foods. ${ }^{26}$

${ }^{23}$ The reader is invited to apply this analysis to the recent $\$ 7$ decision by the Supreme Court in United States v. Penn-Olin Chem. Co., 378 U.S. 158 (I964), reversing 217 F. Supp. IIo (D. Del. 1963). There the arrangement between the two participants in a joint venture was "pregnant" with reciprocity overtones. Neither the Court's opinion nor those expressing the views of the four dissenters mentioned the term "reciprocity"; Consolidated Foods had already been docketed for argument.

${ }^{2 *}$ On this point see Hale \& Hale, Reciprocity Under the Antitrust Laws: $A$ Comment, II3 U. PA. L. Rev. 69 ( 1964$)$. The Hales make a general survey of the problems surrounding antitrust enforcement in this area and conclude that it might be best to let proof of the fact of reciprocity create a presumption that the practitioners enjoy a degree of market power forbidden by $\$ 2$ of the Sherman Act.

Those who favor the analysis offered by Professor Ferguson will find support in the commentary of Almarin Phillips in Phillips, Reciprocity Under the Antitrust Laws: Observation on the Hales Comment, II3 U. PA. L. REv. 77 (I964). The Phillips article should be read in contrast with Hausman, supra note 2I. It should be noted that both of these articles were written before the Supreme Court handed down its decision in Consolidated Foods.

${ }_{25} 5$ TrADE ReG. ReP. (I965 Trade Cas.) I 71518 (S.D.N.Y., July 28, 1965).

20 Thus, at 5 Trade Reg. Rep. at $8 \times 278$, the court, citing Consolidated Foods, said, "It is thus apparent to the court that the applicable rule in a case such as this is that an acquisition which makes reciprocity possible violates $\$ 7$ if the probable consequence of the acquisition is to lessen competition through the use of leverage in one field or another." 
The "novel" aspect of the case was the discussion of the section I charge. In the court's view, the use of a Special Sales Program, where "reciprocity considerations were injected into sales discussions and ... the intent [of such,program] was to rise above the normal considerations of competition by exercising the leverage which existed,"27 resulted in agreements in violation of section I. As the court stated,

- The defendant has systematically injected reciprocal dealing into its sales negotiations. Thus the agreements which are the product of this anticompetitive practice, with the effect of barring competitors from the market, are in restraint of trade, their purpose being to hamper free competition in the market. ${ }^{28}$

Though not a "pure reciprocity case," General Dynamics nevertheless forecasts the use of section $I$ in attacking reciprocal dealing arrangements. The difficult question remaining is whether such agreements are to be deemed per se illegal (as in the case of tying arrangements) or whether the rule of reason is to be applied in judging illegality in a particular factual setting. That "Consolidated Foods silences any argument of per se legality"29 is not to say that it stands for per se illegality. Reciprocity may very well be "normal and expected business practice" and be ancillary to other main lawful business purposes. At least it is clear that considerable more judicial experience with the practice is necessary before condemning any such arrangements without the extended inquiry into purpose, power and effect that the rule of reason envisions. ${ }^{30}$

It is in light of the above observations that the significance of Professor Ferguson's analysis assumes its proper perspective. The assertion by this economist that the socio-economic decisions of our courts often appear to proceed from ill-founded economic premises should be taken as a caution by all who labor in the field of antitrust enforcement. The ever-increasing complexity of our economic horizons forecasts a future in which many trade practices will arise that are calculated to test the ingenuity of those who are vested with the responsibility of antitrust regulation.

The commitment to a free-enterprise system will, in the opinion of this writer, continue as the basis upon which all litigation will stand or fall. Indeed, the language of Judge Learned Hand in his discussion of freedom of the press loses none of its strength when applied to a defense of free enterprise: "To many this is, and always will be, folly; but we have staked upon it our all." "T1 Thus, an economic analysis such as that offered by Professor Ferguson, in which the legitimate economic uses of reciprocity and of tying provisions are set forth, becomes highly relevant not only to our immediate concern but to the future. ${ }^{32}$

\footnotetext{
${ }^{27}$ Id.' at $8 \mathbf{I}_{2} 84$.

${ }^{28}$ Ibid.

${ }^{20}$ Id. at 81283 .

${ }^{30}$ Cf. White Motor Co. v. United States, 372 U.S. 253 (1963).

${ }^{31}$ United States v. Associated Press, 52 F. Supp. 362, 372 (S.D.N.Y. 1943), aff'd, 326 U.S. 1 (1945).

${ }^{32}$ The Supreme Court's attitude toward reciprocity may well be crystallized when, and if, cither the General Dyriamics case or United States v. General Motors Corp., Civil No. 63-80, N.D. Ill., filed Jan, IA, I $6_{3}$, reaches the level of final appellate review.
} 
One factor is certain, and that is that a relationship between the lawyer and the economist must be one of increasing familiarity. Legal decisions without proper economic bases are at best ill-conceived and at worst positively dangerous. Likewise, pure economic analysis is of little compelling value in the courtroom where the forces of social policy are arrayed on either side of an instant question. 